\title{
ANALISIS KEPUTUSAN KONSUMEN DALAM MELAKUKAN PEMBELIAN MAKANAN DAN MINUMAN DI WARUNG HIK
}

\author{
Muzakar Isa, Ahmad Mardalis, dan Liana Mangifera \\ Fakultas Ekonomi dan Bisnis \\ Universitas Muhammadiyah Surakarta \\ Jl. A. Yani Pabelan Kartasura Surakarta 57102 \\ Email: muzakar.isa@ums.ac.id
}

\begin{abstract}
ABTRAKSI
Penelitian ini bertujuan menganalisis kualitas produk, harga, promosi dan lokasi terhadap keputusan konsumen dalam membeli makanan dan minuman di warung HIK. Populasi penelitian ini adalah masyarakat di wilayah Kota Surakarta dan sekitarnya yang pernah menikmati layanan warung HIK di Kota Surakarta. Pemilihan sampel menggunakan metode purposive sampling.Jumlah sampel yang diambil dalam penelitian ini sebanyak 102 orang responden. Penelitian ini menggunakan data primer yang diambil menggunakan wawancara terstruktur dengan bantuan kuesioner. Analisis data yang diggunakan adalah analisis regresi berganda. Simpulan penelitian ini adalah kualitas makanan, harga dan promosi berpengaruh positif dan signifikan terhadap keputusan pembelian makanan dan minuman di warung HIK, sedangkan lokasi berpengaruh positif tetapi tidak signifikan terhadap keputusan pembelian di warung HIK di Kota Surakarta. Pelaku usaha warung HIK harus meningkatkan kualitas produk dengan mempertimbangkan harga yang sesuai serta melakukan promosi sehingga dapat bersaing dengan warung HIK lainnya.
\end{abstract}

Kata Kunci: Keputusan Pembelian, Wisata, Kuliner

\begin{abstract}
This study aims to analyze product quality, price, promotion and location to consumer decisions in buying food and beverages at HIK. The population of this study is the community in the Surakarta and surrounding areas who have enjoyed the service HIK in Surakarta. Sample selection using purposive sampling method. The number of samples taken in this study were 102 respondents. This study uses primary data taken using structured interviews with the help of questionnaires. Analysis of data used is multiple regression analysis. The conclusion of this research is the quality of food, price and promotion have a positive and significant effect to the decision of purchasing food and beverage at HIK, while the location have positive but not significant effect to purchase decision at HIK in Surakarta City. Business actors HIK must improve the quality of the product by considering the appropriate price and conduct promotion so that it can compete with other HIK.
\end{abstract}

Keywords: Purchase Decision, Tour, Culinary,

\section{PENDAHULUAN}

Pariwisata merupakan salah satu sektor penting sebagai sumber pendapatan daerah Kota Surakarta (Isa, 2016). Kota Surakarta terus berbenah untuk mengembangkan sektor pariwisata, baik destinasi wisata, event wisata maupun sarana pendukungnya, dalam mengembangkan ekonomi daerahnya. 
Peningkatan sektor pariwisata di Kota Surakarta terlihat dari meningkatkanya trend masyarakat yang lebih senang bepergian ke berbagai tempat untuk melakukan perjalanan wisata, baik wisata alam, wisata budaya maupaun wisata minat khusus. Salah satu bentuk dari wisata minat khusus adalah wisata kuliner (Isa, 2016).

Perkembangan kuliner di Kota Surakarta terjadi semenjak berabad-abad yang lalu dan mewariskan kekayaan yang tidak sedikit. Kuliner Kota Surakarta terus berkembang sampai sekarang.Wisata kuliner merupakan salah satu bagian dari wisata budaya yang berarti wisata ini memiliki nilai tersendiri di mata wisatawan. Kekayaan kuliner merupakan sebuah modal besar yang harus dimanfaatkan dalam rangka pengembangan ekonomi daerah (Saeroji dan Wijaya, 2017).

Kota Surakarta memiliki aneka kuliner yang menarik, dengan kualitas rasa yang tidak diragukan lagi. Kuliner Surakarta dipandang sebagai potensi pariwisata (Saeroji dan Wijaya, 2017) karena tidak jarang orang datang ke Kota Surakarta hanya untuk mencicipi makanan khas kota ini. Hal ini diperkuat dengan penobatan Kota Solo sebagai Kota Kuliner selain Kota Bandung oleh Menteri Pariwisata. Masakan-masakan yang menjadi ikon ini membantu Kota Solo dalam hal branding, tidak sedikit wisatawan yang menjadikan wisata kuliner di Kota Solo sebagai agenda wajib.

Makanan dan minuman di Kota Surakarta merupakan salah satu potensi bisnis dengan tingkat pertumbuhan yang tinggi karena makanan dan minuman merupakan salah satu kebutuhan utama semua orang dari berbagai kalangan (Wajdi, dan Isa, 2014). Salah satu sub sektor industri makanan dan minuman yang berkembang pesat saat ini adalah usaha makanan-minuman yang disebut dengan "warung HIK". Warung HIK "Hidangan Istimewa ala Kampung" atau wedangan merupakan warung makan yang menyediakan makanan dan minuman. Warung ini beroperasi mulai sore hari, dengan mengandalkan penerangan tradisional yaitu senthir dan juga dibantu oleh terangnya lampu jalan. HIK terkenal sebagai tempat yang egaliter karena bervariasinya pembeli yang datang tanpa membedakan strata sosial, suku, agama dan ras. Mereka menikmati makanan sambil bebas mengobrol hingga larut malam meskipun tidak saling mengenal, membicarakan berbagai hal atau kadang berdiskusi tentang topik-topik yang serius. Harganya yang murah dan tempat yang santai membuat HIK sangat populer di tengah kota sebagai tempat persinggahan untuk mengusir lapar atau sekadar melepas lelah. Beberapa alasan yang menjadi daya tarik tersendiri dari HIK adalah harga yang murah, tempat sederhana namun nyaman untuk bersantai dan ngobrol.

Saat ini banyak warung HIK di Kota Surakarta yang dibuat dan dikelola lebih modern dan profesional. Tanpa mengesampingkan karakternya, sekarang banyak warung HIK menjadi salah satu destinasi wisata yang dikunjungi oleh berbagai kalangan yang berasal dari berbagai daerah. Untuk menjaga keberlanjutan usaha warung HIK, menurut Suriani (2009) ada 5 hal yang harus dipertimbangkan, yaitu: (a) Harga; (b) Kualitas makanan (Citarasa yang khas), (c) Lokasi yang autentik; (d) Fasilitas fisik bangunan yang khas, dan (e) promosi (kemasan dan porsi yang sesuai harga).

Kualitas produk merupakan salah satu factor penting bagi konsumen dalam memiliki warung HIK. Berbagai penelitian sebelumnya menunjukkan kualitas produk merupakan faktor kunci mempengaruhi keputuan pembelian konsumen (Saidani et al., 2013). Kualitas produk harus beriringan dengan penentuan harga yang pantas. Harga menjadi salah satu pertimbangan konsumen dalam melakukan keputusan pembelian (Andaleeb dan Conway, 2006; Samuel et al., 2007; Jahanshahi et al., 2011).

Harga merupakan salah satu prinsip dari bauran pemasaran yang menjadi salah satu faktor penentu dalam pembelian produk disamping faktor-faktor lain. Harga menjadi lebih penting bagi konsumen sebagai tanda dari apa yang diharapkan (Abubakar, 2005). 
Konsumen sering beranggapan bahwa harga merupakan indikator kualitas dan perusahaan dapat mengurangi kualitas produk untuk meminimalkan biaya, sehingga harga yang lebih tinggi merupakan tanda dari kualitas yang lebih baik. Berdasarkan hasil penelitian Alfred (2013), diketahui bahwa harga dan kualitas berpegaruh terhadap keputusan pembelian konsumen. Faktanya, konsumen selalu mempertimbangkan harga dan kualitas dalam membeli. Konsumen merasa bahwa harga yang tinggi mencerminkan kualitas yang baik dari suatu produk. Selain itu menurut Kenesei dan Todd (2003), harga memainkan peran penting dalam pemilihan produk karena konsumen selalu mencari informasi dan membandingkan harga antar warung HIK yang ada.

Pentingnya lokasi warung HIK telah diungkapkan sejumlah peneliti. Berbagai riset menunjukkan pengaruh signifikan kualitas lingkungan fisik rumah makan terhadap kepuasan konsumen dan keputusan pembelian. Penelitian yang dilakukan Babin et al., (2005) menegaskan bahwa lingkungan fisik berperan kuat mempengaruhi hubungan positif dengan keputusan konsumen dalam membeli produk kuliner. Hasil riset Arifin et al., (2011) mengungkapkan, kondisi fisik rumah makan seperti warna, desain, tata lampu dan tata letak berpengaruh nyata terhadap perilaku konsumen. Bahkan hasil penelitian Pecotić, et al., (2014) mengungkapkan, bahwa konsumen bersedia membayar lebih mahal untuk memperoleh kondisi desain interior yang lebih baik. Namun hasil penelitian berbeda diungkapkan Andaleeb dan Conway (2006) bahwa desain dan penampilan fisik rumah makan tidak berpengaruh nyata pengaruh terhadap kepuasan konsumen. Dari beberapa hasil penelitian ini, sangat menarik untuk menelaah bagaimana peran atmosfer rumah makan terhadap keputusan pembelian konsumen.

\section{METODE PENELITIAN}

Populasi penelitian ini adalah masyarakat di wilayah Kota Surakarta dan sekitarnya yang pernah menikmati layanan warung HIK di Kota Surakarta. Pemilihan sampel menggunakan metode purposive sampling. Kriteria tersebut adalah masyarakat yang lebih dari 3 kali mengkonsumsi makanan di warung HIK di Kota Surakarta. Jumlah sampel yang diambil dalam penelitian ini sebanyak 102 orang responden.

Penelitian ini menggunakan data primer yang diambil menggunakan wawancara terstruktur dengan bantuan kuesioner. Data tersebut adalah data perspsi responden tentang kualitas makanan dan minuman, harga, lokasi dan promosi, serta keputusan mereka dalam mengikonsumsi di warung HIK di Kota Surakarta. Analisis data yang diggunakan adalah analisis regresi berganda, yang terdiri dari koefisien diterminan, uji simultan (uji F), dan uji hipotesis (uji t).

\section{HASIL PENELITIAN DAN PEMBAHASAN}

Kota Surakarta memiliki banyak warung HIK yang dikelola secara modern dan professional. Warung HIK merupakan tempat favorit bagi warga Kota Surakarta dan sekitarnya untuk berkumpul dengan keluarga, teman dan kolega bisnis. Sebanyak 102 orang yang menjadi responden penelitian, yang terdiri dari 37 perempuan dan 65 laki laki. Mereka berasal dari Boyolali, Sragen, Karanganyar, Sukoharjo, Surakarta, Ngawi, Purwodadi dan Semarang.

MasyarakatKotaSurakarta dan sekitarnya umumnya lebih dari 1 kali menikmati layanan warung HIK. Dalam kurun waktu 1 bulan, sebanyak 42,2 \% responden ke warung HIK sebanyak 2 kali, sebanyak 17,6\% responden ke warung HIK sebanyak 1 kali, sebanyak $16,7 \%$ responden ke warung HIK sebanyak 3 kali dan sebanyak $8,8 \%$ responden ke warung HIK sebanyak 4 kali, dan lainnya di atas 4 kali mereka ke warung HIK dalam 1 bulan.

Berdasarkan kategori usia, sebanyak 16 responden berusia $\leq 20$ tahun, sebanyak 56 responden berada pada kategori usia antara 21 dan 30 tahun, sebanyak 7 orang berada kategori usia antara 31 dan 40 tahun, sebanyak 
11 orang berada pada kategori usia antara 41 dan 50 tahun, dan sebanyak 12 orang berada pada usia $\geq 50$ tahun.

Pengujian asumsi klasik digunakan untuk memastikan bahwa data yang digunakan dalam kondisi yang baik. Uji ini meliputi uji normalitas, heterokedastisitas dan multikolinieritas.

a. Uji Normalitas. Uji ini digunakan untuk mengetahui apakah data dari masingmasing variabel memiliki sebaran yang normal ataukah tidak. Untuk menguji normalitas data digunakan uji Normal $P-P$ Plot of regression standardized residual (Ghazali, 2015). Hasil analisis menunjukkan besarnya data mengikuti garis regresi sehingga dapat disimpulkan persamaan regresi untuk model dalam penelitian ini memiliki sebaran yang normal.

\section{Normal P-P Plot of Regression Standardized Residual}

\section{Dependent Variable: Keputusan Pembelian}

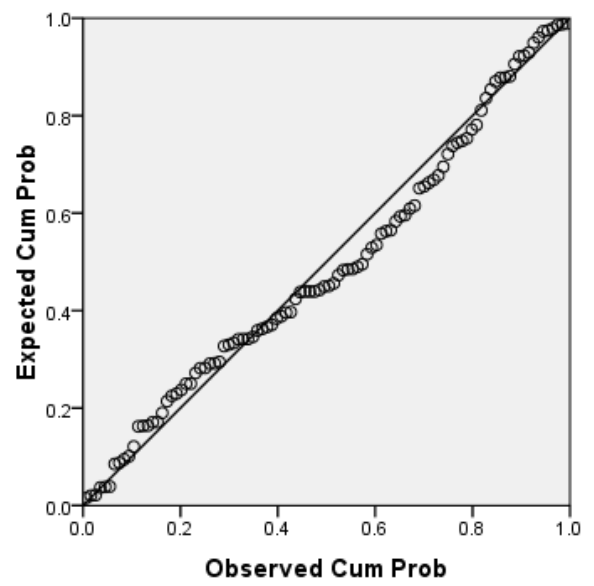

b. Uji Heteroskedastisitas. Uji ini digunakan untuk mendeteksi ada tidaknya heteroskedastisitas dilakukan dengan uji glejser, yaitu dengan melakukan regresi variabel independen terhadap absolut residual variabel dependen dalam regresi utama (Ghazali, 2015). Hasil analisis menunjukkan bahwa besarnya nilai signifikan untuk hasil uji heterokedastisitas terhadap semua variabel memiliki nilai lebih besar dari 0,05 sehingga disimpulkan bahwa semua variabel penelitian bebas dari masalah heterokedastisitas.

c. Uji Multikolinieritas. Multikolinieritas adalah suatu keadaan di mana salah satu atau lebih variabel independen dapat dinyatakan sebagai kombinasi linier dari variabel independen lainnya. Uji multikolinieritas dilakukan dengan melihat nilai VIF dari masing-masing variabel. Jika nilai VIF lebih rendah dari 10, maka disimpulkan bahwa tidak ada multikolinieritas yang serius antara variabel independen dalam model (Ghazali, 2015).Hasiluji multikolinearitas menujukkan bahwa nilai VIF pada uji multikolinearitas variabel penelitian memiliki nilai kurang dari 10 sehingga dapat disimpulkan bahwa semua variabel penelitian tidak terjadi multikolinearitas.

Hasil analisis regresi linear berganda dapat di lihat pada tabel 1 di bawah ini.

Tabel 1. Hasil Analisis Regresi Linier Berganda

\begin{tabular}{lccc}
\hline Variabel Independen & Koefisien & t-ratio & Sig. \\
\hline $\begin{array}{l}\text { Kualitas makanan } \\
\text { (X1) }\end{array}$ & 0,201 & 2,479 & $\mathbf{0 , 0 1 5}$ \\
Harga (X2) & 0,525 & 8,206 & $\mathbf{0 , 0 0 0}$ \\
Lokasi (X3) & 0,097 & 0,936 & $\mathbf{0 , 3 5 2}$ \\
Promosi (X4) & 0,272 & 2,576 & $\mathbf{0 , 0 1 1}$ \\
Konstanta & $=\mathbf{0 , 1 9 6}$ & & \\
$\mathbf{R}^{2} \quad=\mathbf{0 , 6 3 0}$ & & \\
$\mathbf{F} \quad=\mathbf{4 1 , 2 8 8}$ (Sig. 0,000) \\
\hline \multicolumn{4}{c}{ Sumber: Hasil Analisa Data (2016) }
\end{tabular}

Berdasarkan tabel 1 dapat dibuat persaman regresi linear berganda sebagai berikut:

$$
\begin{gathered}
\mathrm{Y}=0,196+0,201\left(\mathrm{X}_{1}\right)+0,525\left(\mathrm{X}_{2}\right)+0,097\left(\mathrm{X}_{3}\right) \\
(0,015) \quad(0,000) \quad(0,352) \\
+0,272\left(\mathrm{X}_{4}\right)
\end{gathered}
$$

Hasil analisis regresi linear berganda ini di atas diinterpretasikan sebagai berikut:

a. Koefisien regresi variabel kualitas makanan $\left(\mathrm{X}_{1}\right)$ sebesar 0,201. Setiap 
kenaikan 1 satuan kegiatan peningkatan kualitas makanan, maka keputusan pembelian makanan dan minuman di warung HIK meningkat sebesar 0,201.

b. Koefisien regresi variabel harga $\left(\mathrm{X}_{2}\right)$ sebesar 0,525. Setiap kenaikan 1 satuan harga makanan dan minuman, maka keputusan pembelian makanan dan minuman di warung HIK meningkat sebesar 0,525.

c. Koefisien regresi variabel lokasi $\left(\mathrm{X}_{3}\right)$ sebesar 0,097. Setiap kenaikan 1 satuan kegiatan perbaikan lokasi dan lingkungan HIK, maka keputusan pembelian makanan dan minuman di warung HIK meningkat sebesar 0,097.

d. Koefisien regresi variabel promosi $\left(\mathrm{X}_{3}\right)$ sebesar 0,272. Setiap kenaikan 1 satuan kegiatan promosi, maka keputusan pembelian makanan dan minuman di warung HIK meningkat sebesar 0,272.

e. Nilai $\mathrm{R}^{2}$ sebesar 0,630 . Variasi keputusan pembelian di warung HIK dijelaskan oleh variabel kualitas makanan, harga, lokasi dan promosi sebesar $63,0 \%$, sedangkan sisanya $37,0 \%$ dijelaskan oleh variabel lainnya diluar model yang diteliti.

f. Hasil uji $\mathrm{F}$ menunjukkan nilai 41,288 dengan nilai sig. 0,000. Model penelitian ini adalah tepat (fit) dan kualitas makanan, harga, lokasi dan promosi secara simultan mempunyai pengaruh signifikan terhadap keputusan pembelian di warung HIK.

g. Hasil uji t untuk variabel kualitas makanan menunjukkan nilai $\mathrm{t} 2,479$ dengan nilai sig 0,015 . Variabel kualitas makanan $\left(\mathrm{X}_{1}\right)$ berpengaruh positif dan signifikan terhadap keputusan pembelian makanan dan minuman di warung HIK.

h. Hasil uji t untuk variabel harga menunjukkan nilai t 8,206 dengan nilai sig 0,000. Artinya variabel harga $\left(\mathrm{X}_{1}\right)$ berpengaruh positif dan signifikan pada alpha 5\% terhadap keputusan pembelian makanan dan minuman di warung HIK.

i. Hasil uji $t$ untuk variabel lokasi menunjukkan nilai t 0,936 dengan nilai sig 0,352 . Artinya variabel lokasi $\left(\mathrm{X}_{1}\right)$ berpengaruh positif tetapi tidak signifikan terhadap keputusan pembelian makanan dan minuman di warung HIK.

j. Hasil uji $t$ untuk variabel promosi menunjukkan nilai t 2,576 dengan nilai sig 0,011 . Artinya variabel promosi $\left(\mathrm{X}_{1}\right)$ berpengaruh positif dan signifikan pada alpha 5\% terhadap keputusan pembelian makanan dan minuman di warung HIK.

Kualitas produk berpengaruh positif dan signifikan terhadap keputusan pembelian makanan dan minuman di warung HIK. Hal ini menunjukkan kualitas produk menjadi pertimbangan konsumen dalam menentukan keputusan pembelian. Responden penelitian mempertimbangkan kualitas produk berdasarkan rasa, tampilan penyajian. Kondisi ini memperlihatkan bahwa konsumen sangat peduli terhadap kualitas produk yang dibelinya di warung HIK. Hal ini sejalan hasil penelitian Latiff et al., (2013) yang mengungkapkan bahwa konsumen memiliki kesadaran untuk mempertimbangkan kualitas makanan dan minuman dalam membuat keputusan pembelian.

Hasil penelitian ini juga menguatkan temuan hasil penelitian Sabir et al., (2014) tentang pentingnya kualitas produk dalam mempengaruhi keputusan pembelian konsumen. Hasil penelitian ini juga mendukung hasil temuan lainnya yang mengungkapkan bahwa kualitas produk berpengaruh positif dan signifikan terhadap minat dan keputusan pembelian konsumen. Konsumen cenderung akan membandingkan kualitas makanan dan minuman sehingga ini menjadi hal penting untuk mempertahankan keunggulan produk warung HIK untuk dapat mempertahankan eksistensinya (Islam et al., 2014).

Harga berpengaruh positif dan signifikan terhadap keputusan pembelian makanan dan minuman di Warung HIK. Hal ini menunjukkan dengan semakin baik pemilihan harga yang ditawarkan akan meningkatkan keputusan pembelian konsumen terhadap produk makanan tersebut. Responden akan mempertimbangkan harga yang sesuai dengan 
daya belinya. Konsumen dapat memperoleh paket lengkap mulai dari makanan hingga minuman dengan harga yang sesuai, sehingga hal ini sangat diharapkan konsumen.

Bentuk promosi yang ditawarkan berbagai warung HIK sangat bervariasi. Pada umumnya warung HIK menetapkan harga yang tidak jauh berbeda antara tempat satu dengan tempat yang lainnya. Perbedaan harga yang ditawarkan lebih disebabkan karena faktor variasi menu. Hal ini sesuai dengan tujuan pangsa pasar utama adalah pelajar atau mahasiswa atauanak anakmuda. Pertimbangan utamanya adalah segi harga yang relatif lebih murah dan mudah dijangkau karena terdapat di sepanjang jalan berbagai kawasan. Hasil analisis ini mendukung temuan Alfred (2013) yang menyatakan bahwa harga dan kualitas produk berpengaruh terhadap keputusan pembelian konsumen. Faktanya, konsumen selalu mempertimbangkan harga dan kualitas dalam membeli. Selain itu, sebelum memutuskan untuk membeli konsumen akan menyesuaikan dengan pendapatan mereka hingga akhirnya memutuskan untuk membeli. Hasil penelitian juga sesuai dengan penelitian Ahmad et al., (2014) yang menunjukkan bahwa harga memiliki hubungan yang signifikan terhadap keputusan pembelian. Dalam menentukan keputusan pembelian, konsumen selalu membandingkan harga produk yang satu dengan yang lain.

Lokasi dan lingkungan warung HIK berpengaruh positif terhadap keputusan pembelian konsumen. Penelitian yang dilakukan Arifin et al., (2011) menegaskan bahwa lingkungan fisik warung HIK seperti warna, desain, tata lampu dan tata letak berpengaruh nyata terhadap keputusan pembelian. Bahkan hasil penelitian Pecotić, et al., (2014) mengungkapkan, bahwa konsumen bersedia membayar lebih mahal untuk memperoleh kondisi desain interior yang lebih baik.

\section{PENUTUP}

Simpulan penelitian ini adalah kualitas makanan, harga dan promosi berpengaruh positif dan signifikan terhadap keputusan pembelian makanan dan minuman di warung HIK, sedangkan lokasi berpengaruh positif tetapi tidak signifikan terhadap keputusan pembelian di warung HIK di Kota Surakarta.

Implikasi teoritis penelitian ini adalah menguatkan berbagai penelitian terdahulu dimana kualitas produk, harga dan promosi merupakan faktor dominan yang mempengaruhi keputusan pembelian. Implikasi manajerialnya adalah pentingnya meningkatkan kualitas produk dengan mempertimbangkan harga yang sesuai serta melakukan promosi sehingga dapat bersaing secara konstruktif. Peningkatan keunggulan warung HIK dapat dilakukan dengan menyajikan produk yang berkualitas. Peningkatkan kualitas dilakukan dengan memberikan keunggulan dari aspek rasa, variasi menu, dan cara penyajiannya.

\section{DAFTAR PUSTAKA}

Abubakar, R. (2005). Pengaruh pelaksanaan bauran pemasaran terhadap proses keputusan pembelian konsumen pada jamu di Banda Aceh. Jurnal Sistem Teknik Industri, 6(3), 54-62.

Ahmad, A., Noor, S. M., \& Wel, C. A. C. (2014). Factors influencing consumers' purchase decision of private label brand products. International Journal of Economic Practices and Theores, 4(2), 101-110.

Alfred, O. (2013). Influences of price and quality on consumer purchase of mobile phone in the kumasi metropolis In Ghana a comparative study. European Journal of Business and Management, 5(1), 179-199.

Andaleeb, S.S., \& Conway, C., (2006). Customer satisfaction and the restaurant industr y: 
an examination of the transaction-specific model. Journal of Services Marketing, 20(1), $3-11$.

Andreti, J., Zhafira, N. H., Akmal, S. S., \& Kumar, S. (2013). The analysis of product, price, place, promotion and service quality on customers' buying decision of convenience store: a survey of young adult in Bekasi, West Java, Indonesia. Inter national Jour nal of Advances in Management and Economics, 2(6), 72-78.

Ariffin, H.F., Bibon, M.F., \& Abdullah, R.P.S. R. (2011). Restaurant's atmospheric elements: what the customer wants. Journal of Asian Behavioural Studies, 1(2), 33-43.

Babin, B.J., Lee, Y., Kim, E., Griffin, M., (2005). Modeling consumer satisfaction and wordof-mouth: restaurant patronage in Korea. Journal of Services Marketing. 19(3), 133-139.

Ghozali, Imam, 2005, Aplikasi Analisis Multivariat dengan Proses SPSS, BP Universitas Diponegoro, Semarang.

Hair J.F., Black, W.C., Babin, B.J., \& Anderson, R.E. (2009). Multivariate data analysis, 7th Edition. Englewood Cliffs. NJ: Prentice Hall.

Hartono, K. (2013). Pengaruh kualitas layanan terhadap kepuasan pelanggan dalam membentuk loya lit a s pel ang g an McDonald's basuki rahmat Surabaya. Jurnal Ilmiah Mahasiswa Universitas Surabaya, 2(2), 1-20.

Isa, Muzakar. 2016. Model Penguatan Kelembagaan Industri Kreatif Kuliner Sebagai Upaya Pengembangan Ekonomi Daerah. Prosiding Seminar Nasional Ekonomi dan Bisnis \& Call For Paper FEB UMSIDA 2016, 352-361.

Islam, Md. M., Islam, M. M., Azim, A. Y. M. A., Anwar, Md. R. \& Uddin, Md. M. (2014). Customer perceptions in buying decision towards Bangladeshi local apparel products. European Scientific Journal, 10(7), 482-497.

Jahanshahi, A. A., Gashi, M. A. H., Mirdamadi, S. A., Nawaser, K., \& Khaksar, S. M. S. (2011). Study the effects of customer service and product quality on customer satisfaction and loyalty. International Journal of Humanities and Social Science, 1(7), 253-260.

Kenesei, Z. \& Todd, S. (2003). The use of price in the purchase decision. Journal of Empirical Generalisations in Marketing Science, 8, 1-21. Kotler, P. \& Gary, A. (2007). Principles of marketing. Prentice-Hall International, Inc: New Jersey.

Kuncoro, Mudrajad, 2001, Metode Kuantitatif Teori dan Aplikasi Untuk Bisnis Dan Ekonomi, UPP AMP YKPN, Edisi Pertama, Yogyakarta.

Latiff, Z.A., Mohamed, Z.A., Rezai, G. \& Kamaruzzaman. (2013). The impact of food labeling on purchasing behavior among non-muslim consumers in Klang Valley. Australian Journal of Basic and Applied Sciences, 7(1), 124-128.

Pecotić, M. Bazdan, V. \& Masardžija, J. (2014). Interior design in restaurants as a factors influencing customer satisfaction. RIThink, 4, 10-14.

Sabir, R.I., Ghafoor, O., Hafeez, I., Akhtar, N., \& Rehman, A.U. (2014). Factors affecting customers satisfaction in restaurant industr y in Pakistan. International Review of Management and Business Research. 3(2):869-876.

Saeroji, Amad, dan Wijaya, Deria Adi. 2017. Pemetaan Wisata Kuliner Khas Kota Surakarta. Jurnal Pariwisata Terapan, No. 1, Vol. 1, 2017

Saidani, B., Rachman, M. A. \& Rizan, M. (2013). Pengaruh kualitas produk dan desain produk 
terhadap keputusan pembelian sepatu olahraga futsal adidas di wilayah Jakarta Timur. Jurnal Riset Manajemen Sains Indonesia, 4(2), 201-217.

Samuel, H., Kosasih, A.V., \& Novia, H. (2007). Perilaku dan keputusan pembelian konsumen restoran melalui stimulus 50\% discount di Surabaya. Jurnal Manajemen Pemasaran, 2(2), 73-80.

Wajdi, M. Farid dan Isa, Muzakar 2014. Membangun Konsep Modal Manusia Yang Berperanan Dalam Kinerja Pemasaran Industri Kecil, Prosiding Seminar Nasional dan Call for Paper, Research Methods And Organizational Studies, ISBN: 978-602-70429-1-9, Hlm. 452464 